\title{
(5)

\section{Skal en pasient som ikke samarbeider miste retten til helsehjelp?}

MEDISINSK ETIKK

\section{REIDUN FØRDE}

E-post: Reidun.forde@medisin.uio.no

Senter for medisinsk etikk

Institutt for helse og samfunn

Universitetet i Oslo

Reidun Førde (f. 1950) er lege og professor i medisinsk etikk. Hun leder nasjonalt arbeid med klinisk etikk-komiteer og er nestleder i klinisk etikk-komité, Oslo universitetssykehus.

Forfatter har fylt ut ICMJE-skjemaet og oppgir ingen interessekonflikter.

\section{UNNI VEIRØD}

Stab pasientsikkerhet og kvalitet

Oslo universitetssykehus

Unni Veirød (f. 1957) er sykepleier, sekretær i klinisk etikk-komité, Oslo universitetssykehus, og rådgiver. Hun har vært ansatt i Norsk pasientforening og vært brukerrepresentant i klinisk etikkkomité, Oslo universitetssykehus.

Forfatter har fylt ut ICMJE-skjemaet og oppgir ingen interessekonflikter.

\section{AUD STENEHJEM}

Nyremedisinsk avdeling

Oslo universitetssykehus, Ullevål

Aud Stenehjem (f. 1957) er ph.d., spesialist i fysikalsk medisin og rehabilitering og i indremedisin og $\mathrm{i}$ nyresykdommer og er avdelingsleder.

Forfatter har fylt ut ICMJE-skjemaet og oppgir ingen interessekonflikter.

\section{OONA DUNLOP}

Nasjonal behandlingstjeneste for CBRNe-medisin

CBRNe-senteret

Akuttmedisinsk avdeling

Klinisk etikk-komité

Oslo universitetssykehus, Ullevål

Oona Dunlop (f. 1958) er ph.d., spesialist i indremedisin og i infeksjonssykdommer, overlege og leder for klinisk etikk-komité, Ullevål/Aker, Oslo universitetssykehus.

Forfatter har fylt ut ICMJE-skjemaet og oppgir ingen interessekonflikter.

Kan man trekke tilbake et livsviktig behandlingstilbud til en samtykkekompetent pasient med destruktiv atferd eller til ruspasienter som ikke møter på dagtid og derfor krever intensivbehandling om natten?

Helsepersonell stilles i dag overfor mange motstridende krav og hensyn. Pasient- og brukerrettighetsloven gir pasienten en rekke rettigheter, slik som retten til medvirkning, rett til nødvendig helsehjelp og klagerett. På den annen side pålegger både 
helsepersonelloven og Etiske regler for leger (§ 12, kapittel 1), leger ansvar for fornuftig bruk av samfunnets ressurser. Ikke sjelden kan pasienters ønske om diagnostikk og behandling komme i konflikt med hensyn til ansvarlig ressursbruk. Å sette grenser for pasienter er krevende både følelsesmessig og tidsmessig, spesielt der behandleren kjenner pasienten godt.

Klinisk etikk-komiteer (KEK) er etablert i alle norske helseforetak for å drøfte etiske dilemmaer, være en beslutningsst $\emptyset$ tte for helsepersonell og sikre at pasientens verdier og interesser er tydeliggjort når viktige avgjørelser tas (1). De første komiteene ble opprettet for mer enn 20 år siden etter initiativ både fra myndigheter og profesjonsorganisasjoner. I dag arbeider komiteene etter et mandat gitt av Helse- og omsorgsdepartementet (2). Noen saker knyttet til enkeltpasienter reiser prinsipielle spørsmål, og noen av disse har tidligere ikke vært adressert (3). Eksempler på dette er prioriteringsspørsmål eller rutiner for behandling av pasienter uten oppholdstillatelse. Slike spørsmål kan bringes frem for lovgivere og helsemyndigheter. De skal ikke, og kan ikke, besvares av helsetjenesten alene. I det følgende vil vi løfte frem et prinsipielt spørsmål som har oppstått etter at flere komiteer har drøftet lignende saker. Vi tar utgangspunkt i en fiktiv pasienthistorie, en kombinasjon av flere lignende pasienter, som drøftes etter en modell som de fleste etikk-komiteene benytter seg av, den såkalte Senter for medisinsk etikk-modellen (SME-modellen). Denne er utviklet av Senter for medisinsk etikk ved Universitetet i Oslo og er inspirert av sentrale aktører i amerikansk klinisk etikk (4). Modellen bidrar til systematikk i drøftingen, og sikrer at etisk relevante spørsmål adresseres før en konklusjon fattes $(2,4)$ (ramme 1). I særlig kompliserte saker er det ikke alltid mulig å komme frem til én konklusjon for riktig handlingsalternativ. Men drøftingen gir den ansvarlige legen et bedre beslutningsgrunnlag.

RAMME 1 MODELL FOR SYSTEMATISK DRØFTING AV ETISKE DILEMMAER (2)

- Hva er de etiske dilemmaene

- Hva er fakta i saken (medisinske og psykososiale), hva er usikkert

- Hvem er de berørte parter og hva er deres interesser og interessekonflikter

- Hvilke verdier, prinsipper er involvert. Lovregulering på feltet

- Hvilke handlingsalternativer er akseptable

- Oppsummering, eventuell konklusjon

Diskusjonen i den saken vi presenterer, baserer seg på komitéreferater fra drøfting av disse pasientene. Mange av komiteene har som mål at pasienten skal være til stede eller være representert, i tillegg til pasientens behandlere, når komiteen drøfter saken. Noen av pasientene var til stede i drøftingene som presenteres her. Dette sikrer at pasientens stemme og forklaringer blir hørt og at pasienten selv får høre hvilke etiske hensyn saken reiser og hvordan disse kan vektes av aktører som ser dilemmaene utenfra (5).

\section{Etiske dilemmaer}

Ofte definerer de som henviser saken det etiske dilemmaet, men komiteen bidrar til at flere dilemmaer identifiseres etter hvert som saken drøftes og flere verdier og verdikonflikter identifiseres. De etiske dilemmaene i denne saken var:

- Er det etisk forsvarlig å nekte en pasient dialyse dersom hans oppførsel er uakseptabel under behandlingen?

- Er det etisk forsvarlig å nekte en pasient akutt dialyse utenom arbeidstid dersom han gjentatte ganger ikke følger opp behandlingen på dagtid? 


\section{Fakta i saken}

Pasienten i 5o-årene har gått i dialyse i åtte år. Han er uføretrygdet og har ingen nær familie. Han ruser seg, men han sier at dette har han kontroll over. Han har startet utredning for nyretransplantasjon flere ganger, men utredningen er avbrutt på grunn av manglende samarbeid.

På dialyseavdelingen dukker det stadig opp situasjoner som er svært krevende for personalet. Han har knust kostbart medisinsk utstyr i raserianfall, spyttet på, brukt grov munn og kommet med trusler mot helsepersonell og truet helsepersonells familier. I sinne har han også revet seg løs fra dialyseslangene under pågående behandling, slik at hepatittinfisert blod sprutet på personale og omgivelser. Personalet og medpasienter blir redde og maktesløse. Avdelingen har funnet det nødvendig å ha en vekter med når pasienten får dialyse, noe som krever ekstraressurser.

Dialyse er en svært kostbar behandling, og i sær når denne må gis utenom arbeidstid. Ofte møter han ikke opp til dialyse i arbeidstiden, men kommer om natten i forkommen forfatning, med behov for akutt dialyse og intensivbehandling. For å unngå dette har personalet ofte ringt eller sendt ut ambulanse når han ikke dukker opp til avtalte timer. De spør seg om det ikke finnes grenser for hva pasienter kan tillate seg uten at det får følger. Avdelingens personale har fått veiledning av psykiatrisk team i hvordan de skal takle psykisk syke og voldelige pasienter. Det har vært avsatt tid til undervisning om etiske dilemmaer og håndtering av utfordrende pasienter.

Psykiater har konkludert med at pasienten er samtykkekompetent. Hans atferd oppfattes å være personlighetsforankret og ikke tilgjengelig for psykiatrisk behandling, noe pasienten heller ikke er motivert for.

Under drøftingen uttrykker han at han ønsker å leve og at han er lei for at han er til bry og skremmer personalet og sine medpasienter. Forklaringen legger han alltid på omgivelsene sine, for eksempel at noen har opptrådt provoserende, eller at hans behov for å sove langt utover dagen ikke er blitt tatt tilstrekkelig hensyn til. Rusvanene sine vil han ikke snakke om. Han mener at de ikke er relevante.

\section{Berørte parter og deres interesser}

Pasienten er samtykkekompetent og forstår konsekvensene av sine handlinger. Han er engstelig for helsen, fortvilet over dårlig dialog med personalet og forklarer manglende overholdelse av avtaler med at han sover dårlig og er svært trøtt om morgenen. Det er lite som tyder på at han tror at han selv kan gjøre noe med situasjon.

Medpasientene blir redde når pasienten får sine raserianfall. Enkelte har avbrutt dialysebehandlingen og forlatt avdelingen, en risiko for deres helse.

Situasjonen har ført til at enkelte av personalet er blitt sykmeldt, og ledelsen er redd for å miste viktige personalressurser, noe som vil gå ut over tilbudet til medpasienter.

Arbeidsmiljøet påvirkes negativt. Søl med hepatittinfisert blod er en risiko for andre. Helsepersonellet har ansvar for behandling av alle pasienter som er på avdelingen.

Ledelsen har ansvar for arbeidsmiljøet og behandlingsmiljøet og økonomisk ansvar for driften av sykehuset.

Samfunnet berøres gjennom bruk av knappe ressurser. I tillegg til at dialyse er svært kostbart, er utstyret han har ødelagt og innleie av vikarer og vektere svært dyrt. Når han kommer med en forverring som skyldes egen atferd, vil han ofte trenge en intensivplass, hvilket ofte betyr at andre pasienter som kunne ha nytte av fortsatt intensivbehandling, må flyttes ut. Det er i fellesskapets interesse å fremme god bruk av, og rettferdig fordeling av, ressursene som brukes i helsetjenesten. Hvilke andre pasienter får ikke nødvendig hjelp når store ressurser brukes på denne pasienten? Hvilke helsegevinst ville en alternativ bruk av ressursene gi for andre sårbare pasienter? 
Når det gjelder hensynet til pasientens pårørende, har en fetter noen ganger kontaktet sykehuset fordi han er engstelig for pasienten.

\section{Verdier og juridiske hensyn}

\section{GJØRE GODT OG IKKE SKADE}

Hvis pasienten ikke får dialysebehandling, vil han dø. Man kan ikke utelukke at pasienten på et senere tidspunkt vil samarbeide om nødvendig behandling. Å nekte ham behandling nå, fratar ham muligheten til å endre seg. Pasienten kan leve i mange år ved dialyse og senere nyretransplantasjon dersom han endrer atferd og levesett. På den annen side har han gått i dialyse i mange år, og dialysepasienter har økt mortalitet (6). Det er vist at opphopning av symptomer i tillegg til uremi hos dialysepasienter er prediktivt for høyere risiko for $\mathrm{d} ø \mathrm{~d}(7)$.

\section{PASIENTENS AUTONOMI}

Autonomiprinsippet tilsier at pasienter kan velge bort behandling eller velge mellom likeverdige behandlingsformer, men pasienter kan ikke velge behandling som ikke er faglig eller etisk forsvarlig. Bak det etiske prinsippet å ha respekt for pasientens autonomi, ligger det noen krav. I denne pasientens situasjon innebærer det blant annet at han må ha fått nok informasjon til at han forstår hva valget gjelder, og han må ha forstått konsekvensene for han selv av å ikke motta behandling. Hos denne pasienten var disse samtykkekompetansekravene oppfylt.

Videre bør pasientens valg og preferanser være konsistente over tid og ikke skyldes ytre press (8). Vår pasient sier at han vil ha behandling, men hans atferd kan tolkes som at han i perioder ikke ønsker det. Man kan spørre om handlingene avdekker ambivalens til behandlingen, siden han så ofte velger å avstå. Dersom et underliggende rusproblem forklarer atferden, kan man også reise spørsmål om pasienter som bruker rus er fullt autonome, eller om mange ikke er autonome med hensyn til rusatferd, men er det i forhold til andre valg. Dersom de må betraktes som autonome, er det da riktig og fremfor alt realistisk å stille krav om at rusmisbruket opphører for at dialysebehandlingen skal ha $\emptyset n$ sket effekt? Hvor autonom er en pasient som ikke har kontroll over temperamentet sitt? En ting er at en autonom pasient kan stilles strafferettslig til ansvar for å forvolde skade på andre, men betyr det også at det er riktig å nekte pasienten nødvendig helsehjelp når han ikke følger opp de kravene som settes?

Kan en pasient kreve behandling når personalet risikerer å bli slått, truet, og blir demotiverte og sykmeldte? Hvor vanskelig skal arbeidssituasjonen være før en pasient nektes behandling på grunn av oppførsel? Her står pasientens interesser også opp mot mange medpasienters interesser.

\section{RETTFERDIGHET}

Rettferdig fordeling av samfunnets goder er et viktig etisk hensyn. Derfor er det nødvendig at det settes krav til samtykkekompetente pasienter, slik at knappe goder utnyttes best mulig. Ved ikke å møte opp til planlagt dialyse forverrer pasienten sin helsetilstand. Både rus og dårlig oppfølging reduserer nytten av behandlingen, som ifølge prioriteringsforskriften er et viktig prioriteringskriterium (9).

Når pasientene ikke følger opp kostbar behandling, påføres også sykehuset økte utgifter. Dette vil i praksis gå ut over tilbudet til andre pasienter. Man har også begrenset respiratorog intensivkapasitet.

Det stilles krav flere steder i helsevesenet. Pasienter som ikke møter opp til time på poliklinikkene, må betale dobbel egenandel. Pasienter med kronisk obstruktiv lungesykom (kols) avkreves evne til samarbeid for å få tilbud om pustestøtte og $\mathrm{O}_{2}$-behandling, pasienter med hiv må møte opp regelmessig for medikamentell behandling på grunn av resistensutvikling, og ved organtransplantasjon stilles det krav til pasientene avhengig av 
type organer. For eksempel har det vært krav om alkoholavholdenhet før levertransplantasjon. Det er særlig relevant at forverring av demens og manglende samarbeidsevne ses på som en kontraindikasjon for kronisk dialysebehandling. I de fleste av disse tilfellene kan utsatt behandling føre til tidligere $\mathrm{d} ø \mathrm{~d}$.

Kravene til ansvarlig oppfølging av svært kostbar behandling gjelder nåtidig og fremtidig utnytting av knappe ressurser. Dette må skilles fra en tenkning om at handlinger og livsstilsvalg gjort i fortid skal «straffe» pasientene slik at behandling av pasienter med «selvpåførte» sykdommer prioriteres ned (10). Selvpåført lidelse er i dag ikke et relevant kriterium i prioriteringsarbeidet (11, 12). Lønning II-utvalget, som drøftet pasientens eget ansvar for sin tilstand som mulig fordelingskriterium, foreslo også at det må skilles mellom ansvar for fortidig og ansvar for fremtidig atferd: «Ingen skal nektes behandling på grunn av at tilstanden skyldes uaktsom eller tankeløs atferd. Dersom nytten av et medisinsk tiltak er avhengig av at pasienten legger om sin livsstil, kan derimot uttalt vilje til endret atferd være et relevant kriterium.» (12).

\section{PROFESJONSETISKE HENSYN}

Nærhetsetiske og profesjonsetiske idealer vil kunne medføre alvorlig moralsk stress. Moralsk stress oppstår når man må handle mot sin profesjonsetikk og moralske overbevisning, for eksempel når man må avvise en alvorlig syk og behandlingstrengende pasient (13). Dette vil sannsynligvis gjelde helsepersonell som ikke kjenner pasienten og ikke har vært involvert i beslutningen om å la være å tilby hjelp. Når de som skal utføre beslutningen ikke kjenner til grunnlaget for denne, kan det være ekstra vanskelig å holde tilbake livreddende helsehjelp. På den annen side må for eksempel unnlatelse av hjertelunge-redning (HLR minus) ofte følges opp av leger som ikke kjenner pasienten.

\section{JURIDISKE HENSYN}

Helsepersonelloven §7 pålegger helsepersonell å yte påtrengende nødvendig helsehjelp. Når pasienten ikke møter til dialysebehandling over tid, krever resultatene av dette, livstruende væskeopphopning og elektrolyttforstyrrelser, strakstiltak.

Videre har pasienter rett til helsehjelp der det er et rimelig forhold mellom nytte og kostnader (9). Spørsmålet er om dette kravet er innfridd når pasienten gjennom sin atferd reduserer nytten av behandling. Når nyresvikt oppstår etter et langvarig og alvorlig narkotikaproblem, kan da tilstanden ses på som endestadiet av en alvorlig sykdom der grunnlidelsen ikke lar seg behandle? Er det mulig å sammenligne dette med terminalstadiet av kreft, hvor kostbar livsforlengende behandling ikke blir gitt fordi forholdet mellom nytte og kostnader ikke er innfridd?

Det finnes en rekke situasjoner der man beslutter ikke å tilby en potensielt livsforlengende behandling (14).

Arbeidsgiver har etter arbeidsmiljøloven § 2-2 plikt til å sikre et fullt forsvarlig arbeidsmiljø. Pasienten påvirker arbeidsmiljøet negativt.

\section{Handlingsalternativer}

Både etiske prinsipper og ulike deler av lovverket pålegger helsepersonell hensyn som er i konflikt med hverandre. Ulike hensyn og ulike aktørers interesser må vektes i en etisk drøfting.

Et handlingsalternativ er å fortsette som før. Dette anses som utilrådelig både ut fra hensynet til medpasienter, ansatte og ressursbruk. Helsepersonell ber om råd for å skape endring på en etisk tillatelig måte.

Å ikke tilby livreddende behandling må anses å være siste utvei, dersom ingen andre endringer fører frem. I første omgang bør man forsikre seg om at alt er gjort for å hjelpe pasienten til å møte til avtalt tid og for at han ikke skal skremme pasienter og 
helsepersonell. Kanskje kan deler av kommunehelsetjenesten mobiliseres for å få pasienten til å møte? Personalet på avdelingen oppfordres til å være tydelige og forutsigbare i samhandling med pasienten, og de bør få mulighet til veiledning. Hensynet til medpasienter, behandlingspersonalet og samfunnets ressurser taler for at pasienten møtes med krav og klare avtaler.

Trygghet i omsorgs- og behandlingssituasjonen kan økes ved å lage en skriftlig avtale med pasienten hvor det står klart hva som forventes av ham og hva han kan forvente av personalet. Det er sannsynlig at pasienter med personlighetsforstyrrelser kan hjelpes med strenge skriftlige avtaler som overholdes.

Avtalen kan inneholde følgende punkter:

- Han er økonomisk ansvarlig for ødeleggelse av kostbart utstyr.

- Det er viktig med én kontaktsykepleier og én pasientansvarlig dialyselege for best mulig dialog.

- Pasienten skal forholde seg rolig og følge personalets anvisninger. Dersom han viser utilbørlig opptreden, må han forlate avdelingen. Om han er misfornøyd med behandlingsopplegget, bes han ta dette opp med sin kontakt.

- Dersom pasienten er forhindret fra å møte, må han gi beskjed og be om ny avtale. Dersom han gjentatte ganger ikke møter opp og kommer om natten med behov for øyeblikkelig hjelp, vil han få tilbud om symptomlindrende behandling på post og dialyse først på dagtid. Pasienten må minnes om at han da setter eget liv i fare.

\section{Konklusjon}

I denne sykehistorien har helsepersonell allerede strukket seg svært langt for å etterkomme pasientens behov for behandling. Å sette grenser og stille krav kjennes etisk vanskelig, særlig der konsekvensene er alvorlige.

Pasienten er samtykkekompetent, og det må forventes at han tar ansvar for sine handlinger og opptreden. En skriftlig avtale vil gjøre dette tydelig. I de tilfellene der rus dominerer atferden, kan det hevdes at sykdom er årsak til pasientens dårlige oppfølging. Her er det tvilsomt om det er realistisk å stille krav om oppfølging.

Samfunnets ressurser er begrenset, og når svært kostbar behandling gis, må det stilles krav til at slik behandling har mest mulig nytte i forhold til ressursbruk. Hensyn til ressursbruk og nytte styrer en del andre situasjoner der det stilles krav til pasientene, for eksempel ved manglende tilbud om organtransplantasjon.

Styrkede pasientrettigheter må følges av forpliktelser. Derfor kan det stilles spørsmål om ikke en konsekvens av uakseptabel atferd til slutt blir at man trekker tilbake tilbudet om dialyse. Da vektes hensynet til arbeidsmiljø, ansatte og medpasienter tyngst.

Dersom man innfører ordninger der det stilles krav til pasienter om samarbeid rundt ressurskrevende behandling, må det være en løpende etisk debatt for å hindre utviklingen av et helsevesen der ressurssvake pasienter som i mindre grad enn andre har full kontroll over livene sine, skyves ut.

\footnotetext{
LITTERATUR:

1. Helse- og omsorgsdepartementet. Nasjonalt mandat for kliniske etikk-komiteer i helseforetak, 2011. http://www.med.uio.no/helsam/tjenester/kunnskap/etikk-helsetjenesten/spesialisthelsetjenesten/nasj onalt-mandat-kliniske-etikkomiteer-helseforetak.pdf(4-4.2017).

2. Førde R, Pedersen R. Manual for kliniske etikk-komiteer i spesialisthelsetjenesten, 2012. http://www.med.uio.no/helsam/tjenester/kunnskap/etikk-helsetjenesten/manualer/manual_rev2015med-korrigert-isbn.pdf (4.4.2017).
} 
3. Førde R, Hansen TWR. Do organizational and clinical ethics in a hospital setting need different venues? HEC Forum 2014; 26:147 - 58. [PubMed][CrossRef]

4. Jonsen AR, Siegler M, Winslade WJ. Clinical ethics. New York,NY: McGraw-Hill Medical Publishing, 2002.

5. Førde R, Hansen TWR. Involving patients and relatives in a Norwegian clinical ethics committee: what have we learned? Clinical Ethics 2009; 4: 121-30.

http://journals.sagepub.com/doi/abs/10.1258/ce.2009.0og018 (4.4.2017).

6. Nordio M, Limido A, Maggiore U et al. Survival in patients treated by long-term dialysis compared with the general population. Am J Kidney Dis 2012; 59: 819 - 28. [PubMed][CrossRef]

7. Amro A, Waldum-Grevbo B, Lippe N et al. Symptom clusters predict mortality among dialysis patients in Norway: A prospective observational cohort study. J Pain Symptom Manage 2016; 51: 512 - 9. [PubMed][CrossRef]

8. Ruyter KW, Førde R, Solbakk JH. Medisinsk og helsefaglig etikk. 3. utg. Oslo: Gyldendal Akademisk, 2014: 139 .

9. Forskrift om prioritering av helsetjenester, rett til nødvendig helsehjelp fra spesialisthelsetjenesten, rett til behandling i utlandet og om klagenemnd.

https://lovdata.no/dokument/SF/forskrift/200o-12-01-1208?qprioriteringsforskriften (4.4.2017).

10. Bringedal B, Feiring E. On the relevance of personal responsibility in priority setting: a crosssectional survey among Norwegian medical doctors. J Med Ethics 2011; 37:357 - 61. [PubMed][CrossRef]

11. Meld. St. 34 (2015-2016). Verdier i pasientens helsetjeneste - Melding om prioritering. Meld. St. 34 (2015-2016). https://www.regjeringen.no/no/dokumenter/meld.-st.-34-20152016/id2502758/ (4.4.2017).

12. NOU 1997. 18. Prioritering på ny - Gjennomgang av retningslinjer for prioriteringer innen norsk helsetjeneste. https://www.regjeringen.no/no/dokumenter/nou-1997-18/id140956/sec1 (4.4.2017).

13. Førde R, Aasland OG. Moral distress among Norwegian doctors. J Med Ethics 2008; 34: 521 - 5 . [PubMed][CrossRef]

14. Helsedirektoratet. Veileder for begrensning av livsforlengende behandling. https://helsedirektoratet.no/retningslinjer/beslutningsprosesser-ved-begrensning-av-livsforlengendebehandling (4.4.2017).

Publisert: 21. august 2017. Tidsskr Nor Legeforen. DOI: 10.4045/tidsskr.17.0038

Mottatt 17.1.2017, første revisjon innsendt 6.4.2017, godkjent 28.4.2017.

(C) Tidsskrift for Den norske legeforening 2020. Lastet ned fra tidsskriftet.no 